\title{
IDENTIFICACIÓN DE BACTERIAS LÁCTICAS COMPONENTES DE LA MICROBIOTA TÍPICA DE LOS TERNEROS CRIADOS EN CONDICIONES ARTIFICIALES ${ }^{1}$
}

\author{
SCHneider, R. ${ }^{2}$, Rosmini, M. ${ }^{2}$, Ehrmann, M. ${ }^{3}$ \& Vogel, R. ${ }^{3}$
}

\begin{abstract}
RESUMEN
Los animales sanos poseen en su tracto gastrointestinal una microbiota típica. La colonización competitiva por parte de los microorganismos benéficos tiene lugar durante los primeros días de vida. Cuando estos microorganismos son administrados como suplemento alimentario vivo, con el objetivo de producir un efecto benéfico sobre el hospedador, son denominados probióticos. El hombre y los animales generalmente poseen Lactobacillus sp. en su tracto intestinal. En el caso de los terneros, estos microorganismos han sido considerados como posibles responsables del control de los efectos de gérmenes patógenos. Tradicionalmente, la identificación de la microbiota animal fue realizada por medio de técnicas morfológicas y bioquímicas. No obstante, se han desarrollado un gran número de metodologías destinadas a identificar los microorganismos en base al estudio de su genoma. Entre ellas, el RAPD es utilizado para diferenciar bacterias lácticas y la técnica de comparación de secuencias de $16 \mathrm{~S}$ rDNA está siendo aplicada para la identificación de bacterias. El objetivo del trabajo fue identificar, mediante técnicas de RAPD y $16 \mathrm{~S}$ rDNA, bacterias ácido lácticas aisladas del tracto gastrointestinal de terneros lactantes sanos criados en condiciones artificiales (guacheras). Los microorganismos utilizados para probar las dos técnicas de identificación genética fueron aislados a partir de la saliva y de diferentes partes de la mucosa intestinal. Las muestras fueron obtenidas a partir de doce terneros con menos de un mes de vida. En particular, Lactobacillus casei, L. salivarius, L. reuteri y Enterococcus faecalis y E. faecium, tiene un interés especial para este trabajo porque existen evidencias de su posible actividad probiótica cuando son administrados a los animales. Los microorganismos encontrados en los animales estudiados han sido informados por otros autores como componentes habituales del ambiente en el que son criados los animales. La técnica de RAPD aplicada fue adecuada para diferenciar los microorganismos aislados a nivel de género y especie, pero no para detectar las diferencias entre cepas.

Palabras clave: terneros, crianza, probióticos, bacterias ácido lácticas, PCR, RAPD, 16S rDNA.
\end{abstract}

1.- Trabajo subvencionado por la Agencia Nacional de Promoción Científica y Tecnológica de Argentina (PICT 99, proyecto ${ }^{\circ}$ 08-06970) y del Programa CAI+D 2000 de la UNL (Proyecto No 14-1-11).

2.- Depto. Salud Pública Veterinaria, FCV (UNL). Kreder 2805 (3080) Esperanza, provincia de Santa Fe. Tel. (03496) 420639, int. 128. E-mail: mrosmini@unl.edu.ar

3.- Technical Microbiology, Lehrstuhl für Technical University of Munich. Freising (Weihenstephan), Alemania.

Manuscrito recibido el 19 de julio de 2004 y aceptado para su publicación el 18 de octubre de 2004. 


\section{SUMMARY}

\section{Identification of lactic acid bacteria form the typical microbiota found in artificial reared calves.}

Healthy animals have characteristic microorganisms in their gastrointestinal tract. The competitive colonisation of beneficial microorganisms takes place on early life. If this microflora is administered selectively as a complement to the diet, it becomes a probiotic. Humans and animals generally have Lactobacillus sp. in their intestinal tract. In calves, they are considered as the possible responsible of the control of the pathogenic bacteria effects. Traditionally, the identification of animal microbiota was carried out by morphological and biochemical techniques. However, molecular methods that study bacterial genome have been developed to identify microorganisms. RAPD was employed to discriminate lactic acid bacteria and 16S rDNA sequence comparison is used for bacteria identification. This work was aimed at applying RAPD and 16S rDNA techniques to identify lactic acid bacteria that colonise the gastrointestinal tract of healthy calves reared under artificial conditions. In order to test the two genetic identification techniques the samples of microorganisms were isolated from saliva and from different parts of intestine. Sampling was carried out from twelve newly born calves. Particularly, Lactobacillus casei, L. salivarius, L. reuteri and Enterococcus faecalis and E. faecium are of special interest as there are evidences of their possible probiotic potencial when administered to animals. The results obtained showed that the intestine of the studied young calves are colonised by germs coming from the environment where they are reared. The applied RAPD technique was able to discriminate between all isolated microorganisms at species level, but it was not sufficient to detect the differences between strains.

Key words: calves, bred, probiotic, lactic acid bacteria, PCR, RAPD, 16S rDNA. 